\title{
GRUPURI ȘI CENACLURI LITERARE DIN REPUBLICA MOLDOVA. PRIVIRE DE ANSAMBLU
}

\author{
Cristina DICUSAR \\ Institutul de Filologie Română „Bogdan Petriceicu-Hasdeu”, Chişinău
}

Rezumat. Tradiția cenaclurilor şi grupurilor literare a fost consolidată în perioada optzecistă în România; tradiție care s-a extins și în RSSM, la sfârșitul anilor '80, și, mai târziu, în statul proaspăt format, Republica Moldova (27 august 1991).

In prezenta comunicare vom face o trecere în revistă a grupurilor, cenaclurilor, atelierelor literare din Moldova post-sovietică, prezentându-le sumar direcțiile și caracterul acestora, comparându-le cu grupările literare din România și analizându-le impactul în formarea scriitorilor de limbă română din Republica Moldova.

Cuvinte-cheie: cenaclu, grup literar, curent literar, atelier literar, scriere creativă.

Abstract. The tradition of literary circles and literary groups experienced a revitalization in the 1980s in Romania: a tradition that extended to the MSSR (Moldovan Soviet Socialist Republic) in the late 1980s, and later to the newly formed state of the Republic of Moldova (August 27, 1991).

In this paper we examine the groups, circles, and literary workshops of post-Soviet Moldova: presenting their directions and characters, comparing them with literary groups in Romania, and analyzing their cultural impacts on Romanian-language writers from the Republic of Moldova.

Keywords: Literary circle, literary group, literary movement, literary workshop, creative writing.

Literatura dintre lumi. De la RSSM la Republica Moldova. Cercurile și școlile literare au mers mereu mână în mână cu varii fenomene culturale și sociale, promovând metode de raportare conceptuală la literatură. Cenaclul de Luni din perioada optzecistă a stat la baza revitalizării tradiției cenaclurilor românești, satisfăcând nevoia scriitorilor (de regulă, nedebutați) de a intra în arena literară $\breve{1}^{1}$.

${ }^{1}$ În România comunistă, a scoate o carte însemna, pe lângă cenzură, mari liste de așteptare, care puteau presupune amânarea publicării (experiența publicării în perioada comunistă, în anii ' 80 , este descrisă în prefața volumului „Flashback 1985” de Ion Bogdan Lefter) În RSSM, tergiversările publicărilor din motive politice erau și ele comune, inclusiv în anii '80 („Din cauza sistării programelor editoriale, alți optzeciști vor debuta după 1991” (Șleahtițchi, 2019, p. 554), scrie Maria Şleahtiţchi referindu-se la o parte din optzeciști care au avut și ei debuturi întârziate). 
În România ceauşistă, dar și în cea postrevoluționară, mai mulți iniţiatori ai unor discuții literare importante cercetau „noul” limbaj poetic, noua estetică. Nicolae Manolescu, Gheorghe Crăciun, Alexandru Mușina, Marin Mincu au fost „spiritele critice directoare, formative și coagulante” (parafrază după Lungu, 2015, p. 6), de care, în opinia criticului Eugen Lungu, duceau lipsă basarabenii ${ }^{2}$. Datorită acestor cenacluri, optzeciștii din România își regizează debuturile (Lefter), prima apariție editorială întârzie în favoarea unei afirmări literare mature.

În Republica Moldova, lucrurile se întâmplă cu (mai mare) întârziere. O bună parte din optzeciști debutează în anii '90: „În 1990, la (...) Literatura Artistică, apăreau Caietele Sarmis ale Cenaclului „Luceafărul” de pe lângă ziarul Tinerimea Moldovei, coordonat de Andrei Țurcanu. Erau primele cu litere românești (...) În cele trei caiete Sarmis au apărut poeme de: Fidel, Lia Țâcu, Ion Ștefănescu, Viorica Căpățână, Andrei Langa, Alexandru Corduneanu și Boris Grigorescu." (Erizanu). Urmează apoi, în 1995, antologia Portret de grup, care include, pe lângă scriitori optzecişti basarabeni, și alte modele lirice, de la Eugen Cioclea la Dumitru Crudu.

În ceea ce ține de generația optzecistă basarabeană, ea s-a manifestat în umbra cenaclului „Alexe Mateevici” (în România, cenaclul „Flacăra”, aparent cu un program similar, este interzis de regim în 1985). Scriitorii care se adunau la cenaclul Mateevici, au fost în avangarda emancipării sociale, ideologice, naționale" în perioada sfârșitului anilor '80: „În Basarabia renăștea poezia mesianică, a atitudinilor civice și patriotice. (...) Literatura, alta decât cea rostită la mitinguri și proteste stradale, trece pe planul secund al receptării. Nu-i timpul finețurilor de limbaj și al meditațiilor textualist-filosofice” (Șleahtițchi, 2019, p. 553). Întrun articol pentru Tineretul Moldovei, Emilian Galaicu Păun ne vorbește despre participanții la cenaclu: „Spre sfârșitul anului 1988, când ședințele cenaclului „Mateevici” luau amploare, brusc poezia sovietică (!) moldovenească s-a trezit din amorțeală drept în stradă și - pentru prima dată în viață a încercat să exprime strada, bineînțeles în limbajul sofisticat al lozincilor comuniste. După câteva poeme grandilocvente tip Agnesa Roșca C. poezia moldovenească a început chiar să cocheteze cu strada; rime de tipul „rămân - român” fiind considerate pietre de temelie a unei viitoare culturi naționale. Dacă aceste texte ar fi fost semnate cu precădere de scriitorii care dintotdeauna au ținut la cultura noastră, astăzi aș fi tăcut. Dar, paradoxal, cei mai (...) apropiaţi prieteni ai Fratelui mai Mare, (...), au început în cor să-și strige crezul de mari patrioți ai neamului, să-și revendice drepturile de martiri." (Galaicu-Păun, 1990, p. 6)33.

2 „Cam de la restructurare încoace (de altfel, mare paradox!), spiritul critic a fost trântit palancă la pământ (Ion Creangă). O bună parte din critici s-au instituționalizat în ale politicii, cei tineri nu-şi pot încropi autoritatea fiindcă nu li se permite." (1990, p. 5).

${ }^{3}$ Galaicu Anul literar $1989=$ „1984” + Un cincinal de poezie ura-patriotică. 
„Procesul firesc al unei literaturi a fost întrerupt, o vână fiind blocată” (Galaicu-Păun, 1990, p. 6), și ține de noua literatură basarabeană să recupereze. Marginalizată de poezia lozincardă, prima poezie postmodernistă basarabeană va ieși la suprafață, după cum am spus, întârziat. Optzeciștii basarabeni, spre deosebire de scriitorii „de estradă”, își asumă un alt „program patriotic”, încercând să adapteze limbajul poetic interriveran la cel de peste Prut. „Locul de muncă” al optzeciștilor e, astfel, la bibliotecă, citind (în mod critic) literatură română, stabilind conexiuni cu literatura contemporană din alte țări, publicând articole, schimbând, în sfầrșit, paradigma poetică modernistă, cu cea postmodernistă ${ }^{4}$.

Anul 1990 este cel al sincronizărilor: se trece, treptat, la grafia latină; chiar și până la căderea regimului, se vorbește și se scrie despre naționalismul românesc (uneori, alături de articole de tipul „Poetul pășind spre comunism”); în fond, se ,activează” gândirea critică și, mai ales, gândirea românească. Începând de la optzeciști putem vorbi chiar și despre o ulterioară dinamică intertextuală între literatura basarabenilor și literatura română de peste Prut.

Nouăzecismul fracturist basarabean. În Republica Moldova, trecerea de la textualismul optzecist la poezia teribilismului cotidian a fost bruscă. Nouăzecismul basarabean nu a existat ca punte de trecere la o altă poetică, aşa cum s-a întâmplat în România cu grupul de la Braşov și nouăzeciștii Cristian Popescu, Iustin Panţa ș.a.. Au existat câţiva autori neîncadrați în Portret de Grup, debutaţi la sfârşitul anilor 1990, nu și un grup de autori cu program/stil similar. Nouăzecismul basarabean se reduce, aproape în întregime ${ }^{5}$,la fracturism (inițiat de Marius Ianuș și Dumitru Crudu, care publică Manifestul fracturist în România, în 1998).

Curentul fracturist, chiar dacă nu e un curent originat din realitățile basarabene, are mulți membri din stânga Prutului: Dumitru Crudu, Mihail Vakulovski, Alexandru Vakulovski, Ștefan Baștovoi, Iulian Ciocan, Mitoș Micleușanu. Inclusiv ca urmare a curentului fracturist, din anii 2000 până acum au apărut câteva centre de greutate în poezia basarabeană, toate având tangențe cu fenomenele literare românești: Atelierul de Scriere Creativă „Vlad Ioviță”, Revista „Stare de Urgență”, grupul HumanZone și cenaclul Republica.

În 2007, se fondează, la Chișinău, revista Stare de Urgență de către Marius Ianuș și Dumitru Crudu, unde publică Alexandru Vakulovski, Cristina Ispas, Cătălina Bălan, Diana Iepure, Ecaterina Bargan ș.a., și poeții grupului (basarabean) HumanZone, fondat în 2005, al căror membri sunt Hose Pablo, Andrei Gamart, Alex Cosmescu, Vadim Vasiliu, Vlad Gatman, Corina Ajder, Daria Vlas. p. 6).

4 „O șansă de integrare ar fi fost limba, în special limbajele artistice” (Galaicu-Păun, 1990,

${ }^{5}$ Notă distinctă face mai ales Iulian Fruntașu, a cărui direcție poetică diferă de cea optzecistă, fără însă a se încadra în teribilismul fracturiștilor. 
Atelierul de scriere creativă „Vlad Ioviţă” este condus de Dumitru Crudu, și se ține la Chișinău, cu întreruperi, din anul 2008. Prin „băncile” atelierului au trecut Emanuela Iurkin, Ecaterina Bargan/Ștefan, Ion Buzu, dar și proaspăt debutații Rodica Gotca, Artiom Oleacu, Artur Cojocaru, Vitalie Colț, Veronica Ștefăneț. De asemenea, în cadrul taberelor creative organizate de acest atelier, participă scriitorii deja afirmați: Aurelia Borzin, Ana Donțu, Anatol Grosu, câştigător al Premiului Eminescu în 2013, Maria Paula Erizanu ș.a. Fără a impune o direcție poetică unică, Atelierul „Vlad Ioviță” a avut rolul de școală de literatură, după modelul Școlii de la Braşov și Cercului 19, condus de Alexandru Mușina.

Un alt punct de convergență a scriitorilor basarabeni a devenit Cenaclul Republica, condus de scriitoarea Moni Stănilă, cenaclu la care au participat și participă poeți și prozatori din generații și cu direcții poetice diferite. Fondat în mai 2011, pe lângă Biblioteca Națională, cenaclul a avut peste 60 de scriitori invitați din România (Vakulovski).

O altă școală literară a fost formată la Bălți, în cadrul Universității „Alecu Russo"'. Școală care a adunat cercetători și scriitori ca Margareta Curtescu, Ghenadie Nicu, Anatol Moraru, Lucia Țurcanu, Virgil Botnaru, Igor Ursenco, Nicolae Leahu, Maria Șleahtițchi, Diana Vrabie, Ana Bantoș ș.a.

Tradiția cenaclurilor, grupurilor, atelierelor literare este una de import în spațiul basarabean. Acestea au avut rolul de a educa practica discuțiilor despre (și pe) texte, provocând (re)lecturi atente ale literaturii contemporane, dar au și prilejuit descoperiri ale unor nume omise, sau ale unor nume noi, abia apărute în ecuația literară. În Republica Moldova, cenaclurile literare, în formatul lor onest, cameral (în opoziția celor „de estradă” sau a celor adepte ale lozincilor patriotarde), abia și-au reluat activitatea în anii 2000, atunci când, în România, activitatea lor devenise mai puțin vizibilă. Ele propun o alternativă de interacțiune cu un public select, citit, interesat de literatură, pe modelul românesc.

\section{Referințe bibliografice:}

1. ERIZANU, Gheorghe. Debut în cumplite vremi.[online] Disponibil: http://erizanu. cartier.md/debut-in-cumplite-vremi-11082.html [citat 03.11.2021].

2. LUNGU, Eugen. Portret de grup: O altă imagine a poeziei basarabene: Antologie. Ed. a 2-a. - Chișinău: Cartier, 2015, 208 p.

3. GALAICU-PĂUN, Emilian. Anul literar 1989= „1984” + Un cincinal de poezie urapatriotică. În: Tineretul Moldovei, 13 iunie, 1990, p. 6.

4. ȘLEAHTIȚCHI, Maria. Literatura în comunism. În: Panorama comunismului în Moldova sovietică: context, surse, interpretări. Iași: Polirom, 2019, pp. 531-556. 
5. VAKULOVSKI, Alexandru. Alexandru VAKULOVSKI // Casă nouă la Republica: lectură de Dmitri Miticov. [online] Disponibil: https://deschide.md/ro/stiri/cultura/ 26406/Alexandru-VAKULOVSKI--Cas\%C4\%83\%C2\%A0nou\%C4\%83-la\%C2\%A0Republi ca\%C2\%A0lectur\%C4\%83-de\%C2\%A0Dmitri\%C2\%A0Miticov.htm [citat 03.11.2021].

6. „Cam de la restructurare încoace (de altfel, mare paradox!), spiritul critic a fost trântit palancă la pământ (Ion Creangă)". În: Tineretul Moldovei, 8 iun., 1990, p. 5.

Notă: Articolul a fost realizat în cadrul proiectului de cercetare 20.80009.1606.03 Contexte socioculturale autohtone şi interconexiuni europene în creaţia populară şi literatura cultă din Basarabia (sec. XIX până în prezent), Institutul de Filologie Română „B. P.-Hasdeu” al MEC. 